\title{
Is de vertrouwenscrisis over?
}

\section{Arnoud W.A. Boot}

De schandalen van Ahold, Enron, Parmalat en WorldCom liggen al even achter ons. Zowaar lijkt de storm overgewaaid. Toch zit de angst er goed in. De financiële markt was tot een paar jaar geleden de grote bondgenoot van de ambitieuze bestuurder. Vandaag de dag is de

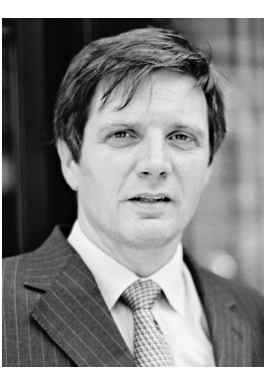
financiële markt verworden tot een zeer sceptische en vooral ongrijpbare opponent.

Heden ten dage lijkt het dat in de financiële markt bijna geen enkel initiatief aanslaat. Voor ondernemingen is toegankelijkheid van de financiële markt slecht. En dit lijkt voor een breed scala aan ondernemingen te gelden. Het is voor de markt dus blijkbaar ook moeilijk om het kaf van het koren te scheiden.

In een euforische periode kan men profiteren van de markt, terwijl men er in een depressieve periode allemaal onder kan leiden. De vraag is nu wanneer deze onzekerheid zich gaat opheffen. Én het kaf dus wel degelijk van het koren kan worden gescheiden, én markten weer 'gewoon' werken.

Maar er is ook goed nieuws: we hebben dit eerder gezien.

\section{De jaren twintig van de vorige eeuw}

De euforie van de IT-revolutie van de jaren negentig, en de problemen die daaruit zijn voortgekomen (beurscrash en misstanden), doen denken aan de jaren twintig van de vorige eeuw. Ook toen was sprake van euforie, met name in de Verenigde Staten, die

Prof. Dr. A.W.A. Boot is hoogleraar Ondernemingsfinanciering en Financiële Markten aan de Universiteit van Amsterdam en Director van het Amsterdam Center for Corporate Finance (ACCF). Hij is tevens oprichtend directeur van het Amsterdam Center for Law and Economics. werd gevolgd door misstanden en een vertrouwenscrisis:

a de euforie van het einde van de Eerste Wereldoorlog tezamen met een technologische revolutie - automobiel, elektriciteit en radio;

b crash van 1929 die hand in hand ging met insider trading, self dealing, et cetera. Bijvoorbeeld banken die willens en wetens obligaties van bijna bankrupte landen verkochten aan particulieren.

Dit laatste geeft al aan dat banken toen een grote rol speelden; ook speelde dat zij veel aandelen en andere vermogenspapieren op de balans hadden staan en hierdoor zelf ook omvielen toen de crash begon, en hiermee dus de gevolgen van de crash versterkten. De diepe economische crisis van de jaren dertig werd juist door het omvallen van de banken veroorzaakt.

\section{Maar banken bleven nu overeind}

Bij de crisis nu spelen banken een meer secundaire rol. Ze zijn niet omgevallen. Integendeel, ze zijn zeer stabiel gebleken. Van een diepe economische crisis is nu dan ook geen sprake. Dit klinkt mooi voor die banken, maar er ging nog steeds veel mis. De meer secundaire rol kwam onder andere door de vertrouwenscrisis die investment banks in de jaren tachtig over zich afriepen. Dit waren de wilde jaren van junk bonds, vijandige overnames, corporate raiders - de jaren van Drexel Burnham Lambert, Ivan Boesky, Michael Milken en andere 'helden'...

Voor de liefhebbers, hele mooie boeken zijn over die tijd geschreven: 'Liar's Poker,' 'Barbarians at the Gate', 'Den of Thieves'. Maar de kern is dat de zware vervolging van de investment banks toen ervoor heeft gezorgd dat deze banken in de jaren negentig niet zelf de grootste misstanden begingen.

Natuurlijk ging er nog steeds veel mis. Waar veel geld is, gebeurt dat... Vergelijk de twijfelachtige rol van 
analisten, de plaatsing van IPO-stukken bij favoriete klanten (bestuurders), et cetera. Maar de echte misdaden werden begaan door hun klanten - de ondernemingen. Voor beleggers was het resultaat hetzelfde nu werden ze via de ondernemingen zelf benadeeld; in de jaren tachtig was het direct door de investment banks.

\section{Nieuwe regulering dreigt}

De vertrouwenscrisis betreft niet alleen de ondernemingen zelf in hun relatie tot de financiële markt, maar naast de banken ook een heel scala aan andere instituties die als intermediair of facilitator optreedt: accountants, credit rating agencies, beleggingsfondsen, et cetera. Een wet- en regelgevend antwoord kon dan ook niet uitblijven.

Evenals in de jaren dertig wordt de crisis ook nu gevolgd door nieuwe regulering. De maatschappelijke reactie is om grote nadruk te leggen op transparantie, toezicht en hiermee samenhangende regelgeving. De Sarbanes-Oxley Act in de Verenigde Staten en allerlei vergelijkbare reguleringen in Europa, alle vooral gericht op transparantie en onafhankelijkheid (bijvoorbeeld van commissarissen en controlerend accountants), proberen hier invulling aan te geven. In de jaren dertig was het zeer ingrijpende regulering die zelfs leidde tot een opsplitsing van investment banks en commerciële banken, de zogenaamde Glass-Steagal Act.

\section{Overreactie?}

Hoewel ik zeker enige sympathie heb voor diegenen die bang zijn voor een wet- en regelgevende overreactie, is aan strengere regulering als het gaat om onafhankelijkheid en transparantie niet te ontkomen. Financiële markten kunnen namelijk alleen functioneren als de integriteit van deze markten wordt veiliggesteld. Regelgeving is hiervoor onontbeerlijk. Uiteraard is dit geen carte blanche, maar de essentie moet zijn dat beursgenoteerde ondernemingen aan zware transparantie en onafhankelijkheidseisen moeten worden onderworpen juist ter bescherming van de vele anonieme beleggers op deze markten. Waar we wel te ver (dreigen) door te schieten, is dat we geneigd zijn niet-beursvennootschappen bijna op dezelfde manier te behandelen. Dit is helemaal fout. Niet-beursvennootschappen - vaak met een zeer beperkt aantal grootaandeelhouders - behoeven geen strak regime. Flexibiliteit is hiervoor nodig. De flexibilisering van het BV-recht, zoals recentelijk door de Commissie De Kluiver bepleit, gaat in deze (goede) richting. Ook de recente notitie van minister Donner over de modernisering van het vennootschaprecht biedt hiertoe enige aanknopingspunten.
Een ander initiatief dat zijn doel gedeeltelijk voorbijschiet, is de voorgenomen nieuwe accountantswet, de WTA. Er kan geen misverstand meer zijn over het belang van controlerend accountants. De schandalen hebben in ieder geval gezorgd voor een geweldige 'rehabilitatie' van het belang van het beroep. De WTA speelt hierop in, en probeert onder andere de onafhankelijkheid van de controlerend accountant te waarborgen, met ook een toezichtregime via de AFM. Waar de wet fout loopt, is dat het een bereik kiest dat veel breder is dan alleen beursgenoteerde ondernemingen (en in het verlengde daarvan organisaties met groot maatschappelijk belang). De toezichtsrol en strenge vergunningenplicht zou moeten worden toegespitst op deze kleinere doelgroep. Het bereik nu is onnodig groot. Dit is niet alleen vanuit een toezichtsrol moeilijk, maar heeft volgens mij ook geleid tot een verwatering van de onafhankelijkheidswaarborgen in de wet. Voor beursgenoteerde ondernemingen zijn ze mijns inziens te licht ${ }^{1}$.

\section{Actie is dus geboden}

Mijn boodschap is duidelijk: actie is wel degelijk geboden. We leven in een zeer sceptische wereld. De schandalen die we hebben gezien, bieden heel wat rechtvaardiging voor een sceptische houding. Weinigen zullen ontkennen dat er uitwassen zijn en dat deze schadelijk zijn. Aandelenmarkten lijken het kwade in de mens naar boven te brengen. Het toegenomen belang van aandelenopties, en de hiermee samenhangende fixatie op aandelenkoersen, geven ongetwijfeld aanleiding tot twijfelachtig gedrag. En weinig moeite is nodig om in Nederland vergelijkbare praktijken bloot te leggen. Onze traditioneel redelijk prudente, zo niet Calvinistische beloningspraktijk is in rap tempo naar de Amerikaanse praktijk toegegroeid. Om met Herkströter te spreken: 'Het was zo eenvoudig: je betaalde ze een goed salaris en daarmee basta.' Misschien is dit wel onterechte weemoed naar het verleden, de transparantie liet vroeger ook te wensen over, maar misschien hadden we het niet in de gaten....

Het is uiteraard veel te simplistisch om al dit toe te schrijven aan de fixatie op aandelenkoersen. Belangrijke maatschappelijke trends, zoals de individualisering en het afnemende samenhorigheidsgevoel, zetten waarden en normen onder druk. Wat hiermee ook samenhangt, zijn een toenemende achterdocht - eerst zien dan geloven - en toenemende zorgen over belangentegenstellingen.

\section{Noot}

1 Via de richtlijnen van het NIVRA is wel sprake van enige differentiatie. 